\section{Ethical Lingua}

Journal of Language Teaching and Literature

ISSN 2355-3448 (Print)

ISSN 2540-9190 (Online)

Volume 5, Number 2, August 2018

pp. $200-211$

\title{
The Power of Speech by Medicine Vendor
}

\author{
Musfirah \\ musfirahvire@gmail.com \\ Universitas Cokroaminoto Palopo, Indonesia \\ Received : 3 August 2018; Accepted: 3 September 2018 \\ URL : : http://journal.uncp.ac.id/index.php/ethicallingua/article/view/1051 \\ DOI : $\quad$ https://doi.org/10.30605/ethicallingua.v5i2.1051
}

\begin{abstract}
The speech of medicine vendor contains power to convince the costumers. This study is aimed at investigating the linguistics features used in the in the speech of medicine vendor. This study is descriptive qualitative in analyzing and displaying the data. The techniques of analyzing data were transcribing the utterances, translation the data into English by applying morpheme by morpheme translation and idiomatic translation, and identifying the linguistics features of medicine vendors' speech. The result of this study revealed that parallelism is one of the linguistics features used in the speech to build a power.
\end{abstract}

Keywords: power; linguistic feature; medicine vendor 


\section{Introduction}

Language contains the power to influence people. This is especially true in the fields of commercial field. The choice of language to convey specific messages with the intention of influencing people is vitally important. In relation the power, Dijk in Margareth et al (2001), pointed out that power and dominance are related each other. Power involves control, namely by (member of) one group over (those of) other groups. In other words, when someone has dominance in position, wealth, and status they can be powerful to authorize other people which less dominated. This kind of power is so called institutional power. For instance, in a court, a judge decides the punishment to the accused one (Fairclough, 1989).

On the contrary, Mooney et al (2011), believed that the power does not only come from institution (position, status and wealth) but also from the language that is used. It categorized as symbolic power. In this term, Mooney viewed language symbols, so it refers to the link between power and language. Power and dominance do not only influence the language; the more obvious is one influence over people through language. People can do many things with language.

It is the medicine vendors that show how the power of language influences people. In this case, they use so many strategies in selling and promoting their products, one of them is using the good language to communicate in order to convince, influence and persuade consumer. This example was taken from Fajar online newspaper, when a traditional medicine vendor said "Cukup dioles saja rambut anda akan hitam seterusnya". After being said, the consumers directly buy that product. It indicates that this sentence has a power to convince the people. Based on the medicine vendor phenomenon, the researcher attempts do this research under the title "the power of speech by medicine vendor". This study is aimed at investigating the linguistic features used in the speech of medicine vendor.

There are two previous studies related to power of speech. Hasyari (2013) conducted the research with title The Power of Ritual Speech in Maddoja Bine Ritual in Pinrang Regency. This study focused on analyzing the power of material symbol which is used in Maddoja Bine ritual. The result of this study was that Maddoja Bine ritual is a traditional ritual done by people who want to plant their rice. This ritual held in order to get a good crop in the harvest time. Moreover, there were several materials used in Maddoja Bine ritual and people believe that those materials have their own power, such as kembokang and wae rinung (water and bowl) symbolized as peaceful life, it means that rice are safe from all of troubles such as pests, mouse, other plants, and also good condition, kaluku lolo (green coconut) symbolized the strength. It means that the rice can 
Musfirah:

The Power of Speech by Medicine Vendor

grow tall and strong, pellang (candlenut stick) symbolized stronghold. It means seeds survive until the harvest times comes, benno' (popcorn) is derive from corn, but when it becomes a benno', it becomes bigger than before, thus, it means that the rice can grow as many as possible.

Unlike Hasyari, Padang (2013) in his research under the title The Power of Ponto Bannang Ritual Speech in Toraja described the power of speaker called Tomina in ponto Bannang ritual. The finding shows that Tomina is an honored man because he must come from a middle and higher class, thus he has a power to making a decision.

Even though those studies above concerned with the power, the difference from those studies above is this study focuses on describing the linguistic feature which is used in the speech. Moreover, the data of this study is taken from medicine vendor's speech which does not relate to the culture.

In addition, the major objective of this study was to investigate linguistic feature used in the speech of medicine vendor. Then, this study provides the explanation about the power of speech especially for symbolic power and this research presents the influence of using particular linguistic features that inform people the strategy of how to attract the attention or to persuade people.

\section{Method}

\section{Research Design}

This research aims to analyze how the power of language that is used by medicine vendors to persuade and convince the consumers. Furthermore, the method applied in this research is descriptive qualitative. It has been done, because the findings of this research describe the context and all of the social situations including; space, actors, activity (Spradley, 1980), stated that the qualitative analysis must be deals with social situation. Moreover, this research identifies the linguistic features and elaborate denotational power that are employed in the speech to construct the power of medicine vendor.

\section{Social Situation}

Based on the Spradley (1980), the qualitative research uses social situation to observe the object of research. It consists of place, actor, and activity. This research conducted in Pantai Losari, Makassar, South Sulawesi at 08.06 am on Sunday morning. It is known that, Pantai Losari has become one of the crowded places in Makassar for people gather including sellers especially on Sunday. Thus, it is chosen because the researcher is able to observe directly how medicine vendors sell their products. Then, the actors are medicine vendors, both women and men. In this case, the activity of medicine vendor includes introducing and promoting their products, serving the consumers, persuading the consumers. 


\section{Procedures of Collecting Data}

In conducting this research, the researcher used grand tour observation. According to Sugiyono (2013), grand tour observation is doing observation generally. Thus, in collecting the data, the researcher records all of the medicine vendors which is get involved in selling products. It has been recorded by using Samsung camera digital. Then, from all of the collected recordings, the researcher chose one of them to be data by applying purposive sampling.

\section{Techniques of Analyzing Data}

Firstly, in order to analyze the data, the researcher transcribed selected data. Secondly, after transcribing the selected data, the researcher translated the Indonesian utterance into English by applying morpheme by morpheme translation an idiomatic translation. In answering the first research question, the researcher then, identified the linguistic features that employed in the speech of medicine vendor. To identify what kind of linguistic features used in the speech, the researcher needs to read the data several time. Afterwards, it is classified according to their type. Then, the researcher analyzed them include the internal element of the utterance such as the prefixes, suffix and the use of particular words that characterized certain linguistic features, and the classes of the words. That way is meant to show deeply how linguistic features contribute to build a power in the medicine vendor's speech.

In addition, the researcher analyzed the whole structure of utterance based on Halliday (1985), in this case the illocutionary acts of medicine vendor's utterance. It has been analyzed by using Austin's speech act theory. To answer the second research question, the researcher applied the functional semiotic theory by Silverstein which focused only on denotational text.

\section{Results \& Discussion}

The researcher found that parallelism is one of the linguistic features used in the speech of medicine vendor. These kind of linguistic feature is contained in two kinds of events; narrating and narrated event. The narrating events started from the utterances below. In the narrating event, the data show how the medicine vendor constructs the text or the speech in order to convince and persuade the consumers.

$\begin{array}{lllll}\text { (1) Nih } & \text { coba } & \text { liat } & \text { mata } & \text {-nya } \\ \text { Interj. } & \text { try } & \text { look } & \text { eyes } & \text {-Poss. }\end{array}$

Let's have a look on her eyes

The first narrating event of medicine vendor begins as it is said in utterance (1) above. The interjection nih in the utterance above is identified as the Phatic function which is nih used to confirm that the contact is still there and it is intended to get the attention of the consumers. In addition, the referential function, which is 
Musfirah:

The Power of Speech by Medicine Vendor

nih emphasis that what he is going to say is what has actually happened. Next, the verb coba (let's) and liat (look at) have a function to invite the consumer to see what is happened on someone's eyes. In utterance (1) the medicine vendor narrates that he was going to tell the truth.

(2) Jangan mau tunggu cerita besok lusa

Do not want to wait story tomorrow day after tomorrow

Don't wait until tomorrow

(3) Sekarang tidak ada per-ubah -an lebih-lebih besok Now do not exist Pre. change Suff. RED-more tomorrow

now there is no more change-over tomorrow

In the utterances of narrating event (2) and (3) the medicine vendor started to persuade the consumer. This persuade way is especially presented in utterance (2) by using negative strategy. It is identified by the use of negation word jangan (do not). The function of word jangan (do not) actually to warn the consumer that not to tow for curing the eyes. Also, from that statement it contained the illocutionary act that is to persuade the consumer to buy that medicine.

Then, the medicine vendor begins to narrate what is really happened on her patient's eyes at that time. It is getting well; the clod of meat in the eyes is thinner. This is shown in the utterances (4) to (7) as follows;

(4) Tambah lama tambah me-tipis

More long more Pre-thin

Gradually dwindling

(5) Nih coba liat dia rabun dia punya mata

Look let's look 1.sg myopic $1 \mathrm{sg}$ have eye

Let's have a look her eyes, hers are myopic

(6) Ee coba liat

try look

Ee let's have a look on her eyes

(7) Tadi tebal sekali

Just now thick too

Previously, it was very thick

The situation of medicine vendor when he said those statements above is there was a patient which her eyes was being cured by the medicine vendor and her eyes have been dropped by the medicine. Then, the medicine vendor was standing in front of his patient and audiences. 
Next, the medicine vendor also narrated that the patience's eyes is getting well because his medicine, it is the fact and he is not lie. This narrating event presented in utterance below;

$\begin{array}{lllll}\text { (8) Tidak ada } & \text { cerita saya punya ramuan } \\ \text { Do not there is/are story } & 1 \text { sg have herb }\end{array}$

This medicine is trusted

By looking at narrating events in the utterances (1) to (8) above, the researcher concluded that the medicine vendor is going to say that his medicine is really good in curing the eyes. The parallelism is also found in the narrating events. Those are found in the utterances as follows;

(9) Tidak ada efek samping

Do not there is/are effect side

There are no side effects

(10) Tidak ada bahan-bahan kimia

Do not there is/are RED-ingredients chemicals

There are no chemical ingredients

The parallel lines above contain double functions. First, it suggests that his medicine is efficacious and really safe to consume because there are no bad effects. Second, it informs that his medicine has no chemical ingredients. Furthermore, those are repeated again until several times in utterances below;

(11) tidak ada efek samping

Do not there is/are effect side

there are no side effects

(12) Tidak ada bahan-bahan kimia

Do not there is/are RED-ingredients chemicals

There are no chemical ingredients

(13) ee tidak ada efek samping itu Pak

Ee do not there is/are effect side Deic. Sir

There are no bad effects Sir

(14) Tidak ada bahan-bahan kimia

Do not there is/are RED-ingredients chemicals

There are no chemical ingredients

(15) tidak ada efek samping

Do not there is/are effect side

there are no side effects 
Musfirah:

The Power of Speech by Medicine Vendor

(16) Tidak ada bahan-bahan kimia

Do not there is/are RED-ingredients chemicals

There are no chemical ingredients

(17) tidak ada efek samping

Do not there is/are effect side

there are no side effects

(18) Tidak ada bahan-bahan kimia

Do not there is/are RED-ingredients chemicals

There are no chemical ingredients

(19) tidak ada efek samping

Do not there is/are effect side

there are no side effects

(20) Tidak ada bahan-bahan kimia

Do not there is/are RED-ingredients chemicals

There are no chemical ingredients

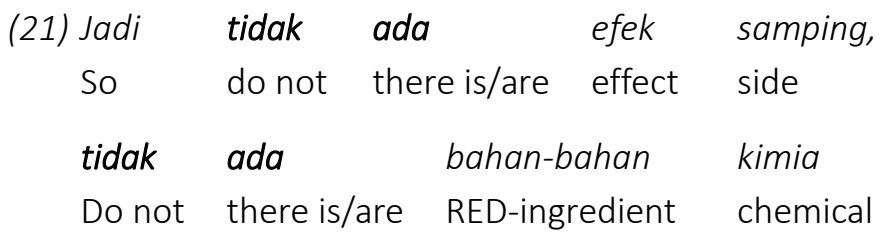

There are no bad effects, there are no chemical ingredients.

Because of those statements are repeated many times, then the researcher assumes that these points are really important. The point that seen from those utterances above is the medicine vendor actually does not only assert or say that his medicine is trusted to be consume but also he attempts to convince and persuade the consumers to buy his product. The speech acts that is done by the medicine vendor is what the Austin called is illocutionary act. Also this illocutionary act occurs in the level of parallelism.

In the narrating events in the utterances (22) and (23), the medicine vendor then attempted to make sure that what has he said is a truth. This narrating event also presented in the parallel lines as follows.
(22) Permisi, ada yang mau baca-baca?
Excuse me there is REL want to RED-read
Silahkan
please

Excuse me, is there anyone wants to read? Please 


$\begin{array}{rlllllll}\text { (23) Permisi } & \text { bapak } & \text { ibu, } & \text { ini } & \text { yang mau baca-baca } & \text { silahkan } \\ \text { excuse me } & \text { Sir } & \text { Mam } & \text { Deic } & \text { REL } & \text { want to } & \text { RED-read } & \text { please }\end{array}$

Excuse me, Sir, Mam. Here is it, if you want to read, please

Those parallel lines are intended to do different thing. The parallel lines before are functioned to convince and persuade, but those statements above are intended to prove. In other words, if the consumers do not belief that the medicine is really safe, they can directly read it.

One of the strategies to persuade the consumer in the narrating event is that by using the negative strategy as presented below;

(24) Ya endak usahbeli
Yeah do not need buy

Do not buy

(25) Saya tidak suruh beli ya

I do not command buy yeah

I do not ask for you to buy

(26) Tapi hari ini Pak

But day Deic Sir

But today Sir

(27) Jangan tunggu saya minggu depan

Do not wait I week front

Do not wait for me next week

(28) Satukali lima tahun belum tentu jumpa dengan saya
One times five years have not certain meet with ।

Once in five years you might not be meeting with me

(29) Jangan tunggu saya minggu depan bahwa ada di sini

Do not wait I Sunday front that exist Prep here

Do not waiting for me for next week that I am here

(30) Tidak

Do not

Do not.

The negative strategies that is covered in parallel lines above are identified by the presence of tidak (do not) and jangan (do not). These negative strategies are not only functioned as informing that he will not come here anymore in this time and warning, but also these negative strategies are functioned to persuade the consumers that just buy and get it now. 
Musfirah:

The Power of Speech by Medicine Vendor

\section{Narrated Event}

The narrated events in the medicine vendor's speech begin from the utterance which is presented in the parallel lines as follows;

$\begin{array}{cccl}\text { (31) orang-orang dulu } & \text { Pak yang } & \text { di-pakai terapi adalah daun sirih } \\ \text { RED-people ago } & \text { sir REL } & \text { Pass.-use therapy is } & \text { leave betel-vine }\end{array}$

Sir, earlier, people used betel leaf for therapy

(32) daun sirih Pak ya

Leave betel-vine Sir yeah

betel leaf Sir

(33) dia ambil

3sg take

They take

(34) dia kunyah-kunyah

atau dia rebus atau dia Anu

3sg RED-chew

or $\quad 3 s g$ boil or

3sg what's-his-name

They chew it or they brew it or what is it

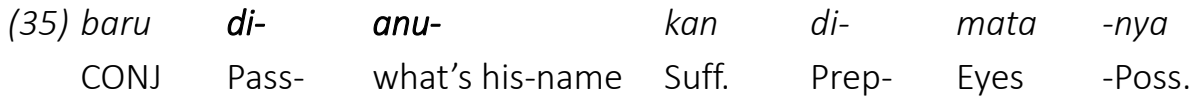

Then, it what is it in their eyes

$\begin{array}{clll}\text { (36) ya } & \text { terang } & \text { juga } & \text { dia punya mata } \\ \text { yeah } & \text { light } & \text { also } & 3 s g \text { have eye }\end{array}$

They have a clear sight

In this case, the device that characterizes the narrated events is the use of word dulu (deictic of time); it points out to the past event which refers to what people did in the past. The point of the utterances above that betel leaf which is used by earlier people can make their eyes is bright and healthy.

Then, as it can be seen the word daun sirih (betel leaf) is repeated again to the next utterance (28). Before uttering those statements above, the medicine vendor firstly mentioned the five ingredients of his medicine and he also said that one of them is betel leaf. Thus, the researcher assumed that what the medicine vendor did by using the parallelism is to emphasize and convince that his medicine is extremely good and efficacious in keep eyes healthy.

Again, the researcher concluded that, the medicine vendor does not only say or tell what the people did in the past but also to emphasize and convince the consumers about his product. Then, the medicine vendor also narrated that he is not only selling his medicine in Makassar, but in Bali as well. It is presented as follows. 


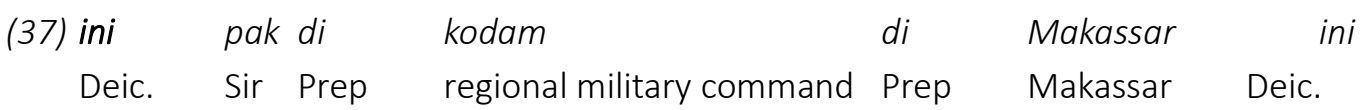

Sir, this is when I was in regional military command in Makassar

$\begin{array}{rllll}\text { (38) ini } & \text { di- } & \text { kodam } & \text { di } & \text { Makassar } \\ \text { Deic } & \text { Prep } & \text { regional military command } & \text { Prep } & \text { Makassar Deic }\end{array}$

This is when I was in regional military command in Makassar

(39) kalo ini di Gapura di Bali

if Deic. Prep. Gapura Prep. Bali

This is when I was in Gapura in Bali

(40) karena setiap acara Galungan saya di Bali

because every event Galungan I Prep. Bali

Because every Galungan event was held, I was in Bali

(41) ya setiap acara Galungan saya di Bali

yeah every event Galungan I Prep. Bali

yeah, when Galungan was held, I was in Bali

(42) ya setiap acara galungan di Bali di Negare

yeah every event Galungan Prep. Bali Prep Negare

yeah, every Galungan event was held in Bali in Negare

(43) ee kalau ada acara di Kuningan saya di Emas

ee if there is event Prep. Kuningan । Prep. Emas

If there is an event in Kuningan, I was in Emas

(44) ya kadang jugasaya meng- ada -kan Peng- obat -an yeah sometimes also I Pre- there is -Suff. Pre- medicine-Suff.

Sometimes, I did the curing

(45) di mana ee di Singaraja di Bali

where ee Prep. Singaraja Prep. Bali

where is it, umm in Singaraja in Bali

(46) iya Sembilan kabupaten di Bali

yes nine district Prep. Bali

yeah, nine districts in Bali

(47) saya pernah meng- ada -kan peng- obat -an

I ever Pre- there is -Suff. pre- medicine -Suff

I ever did the curing 
Musfirah:

The Power of Speech by Medicine Vendor

The next characterization of narrated events in the medicine vendor speech is that deictic ini (this). The way of medicine vendor narrated his self-regard to the what has been done in past, he uses the strategy by using the deicticini (this)that refers to the place where the medicine vendor ever sells his product; regional military command and Bali. Although, these places are so far from Pantai Losari in Makassar. In this case, the medicine vendor as if made the distance of Bali is really close to Makassar by using the deictic ini (this). It is known widely that the Deictic ini (this) means that something is pointed is close to the speaker. It is so called as presentative which means that the reduction of special distance. Likewise, the deictic ini (this) and Bali is also presented in parallelism. The medicine vendor actually wanted to convince that he is a professional seller because he ever sell in many places exactly in Bali.

Overall, it can be concluded that the illocutionary act is occurred in parallelism, and then it builds a power in the speech of medicine vendor. From the beginning of the utterance, the medicine vendor informed that some facts, which is the information about the reason why and how earlier people keep their eyes health. Then, by looking at utterances (31), (32), (33), (34), (35), and (36), he comes to the factors or causes which influence the eye's condition. Afterwards, he also told that what is happened if the consumers ignore the eyes' health. The last, the medicine vendor come to the solution which contained his intention to persuade the consumer to buy his product. The point of medicine vendor is to convince and persuade the consumers.

This illocutionary act occurs in the level of parallelism. In the relation to illocutionary act, Austin (1962), stated that illocutionary act is the act that the speaker intends to do in saying something. It is an act performing some action in saying something. From the data above and the medicine vendor said something about his product that is his medicine is efficacious and really safe to consume because there is no bad effect and also it informs that his medicine has no chemical ingredients his medicine is trusted to be consumed. Further, by saying those parallel statements another thing that is done by medicine vendor is to convince and persuade consumers to buy his product. In other words, those parallel lines contained the illocutionary act (Bloor, 1995).

\section{Conclusion}

In conclusion, the finding and discussion have shown that how the relationship between power and speech. The production of power is achieved by particular linguistic features. In addition, the researcher assumed that these particular linguistic features contain a power to make the unequal position in communication between medicine vendor and audiences. Medicine vendor is successful in constructing his self-identity as professional medicine vendor which means that he knows more all about eyes rather than his audience. 


\section{References}

Austin, J. L. (1965). How to Do Things with Words. Oxford: Oxford University Press.

Bloor, T. \& Meriel. (1995). The Functional Analysis of English. Oxford: Oxford University Press.

Fairclough, N. (1989). Language ad Power. New York: Longman Inc.

Hasyari, M. (2013). The Power of Speech in Madoja Bine Ritual in Pinrang Regency (Unpublished Thesis). Makassar: Universitas Hasanuddin.

Hurford, J. R. \& Heasley, B. (1983). Semantics: A Course Book. Cambridge: Cambridge University Press.

Mooney, A. (2011). Language, Society, and Power. New York: Routledge.

Padang, Y. S. (2013). Power of Ponto Bannang Ritual Speech in Toraja (Unpublished Thesis). Makassar: Universitas Hasanuddin. 